\title{
Refining the Criteria for Delineating Côla and Periods: Some Remarks on the First and Second Steps of "Sound Mapping"
}

\author{
Priscille Marschall \\ Université de Lausanne, Institut Romand des Sciences Bibliques
}

\begin{abstract}
This article challenges the way côla and periods are delineated by exegetes involved in the socalled "sound mapping" approach. Specifically, the author argues that certain criteria for identifying côla and periods that are provided in both the initial version of the method outlined by Margaret E. Lee and Bernard B. Scott (2009) and the refined version proposed by Dan Nässelqvist (2015) conflict with the data from ancient sources. In other words, the criteria typically used for delineating côla and periods fail to accurately reflect the ancient conventions of structuring prose texts. Given the crucial role of the notions of côlon and period for the approach of "sound mapping," further investigation into the rhetorical treatises from the Graeco-Roman world is warranted. Such an investigation, as this study aims to show, allows us to get a deeper understanding of the ancient system of colometry and to lay the foundation for a more historically-informed set of criteria.
\end{abstract}

Key Terms: ancient rhetoric, aurality, sound analysis, style, colometry

\section{Introduction: "Sound Mapping" - an Emerging Method in New Testament Exegesis}

Interest in the oral and aural characteristics of the NT is in the air. After a long history of "literary exegesis" that considered early Christian texts to be silent compositions, scholars have gradually begun to seriously consider these works as having been intended first and foremost to be read aloud and received aurally. This is a trait they share with the majority of texts, either poetry or prose, that circulated in Graeco-Roman antiquity. ${ }^{1}$ Among the approaches that have been intended to better account for the oral and aural aspects of NT texts, "performance criticism" is probably the most familiar. This term, coined by David Rhoads (2006a; 2006b), designates a method aimed at reconstructing

\footnotetext{
${ }^{1}$ The number of studies devoted to the oral and/or aural characteristics of NT texts has increased since the 1980s, following the pioneering work of Kelber (1983). For an overview of the two first decades of biblical scholars' engagement with the topic of orality, see Hearon (2004).
} 
the context and modalities of the performance of biblical texts. The focus of this approach is on the act of delivery-including both the performance by the speaker and the reactions of the audience ${ }^{2}$ - but also on the role of performance in the composition process (Wire 2011). "Sound Mapping” represents another, lesser known approach. Its purpose is to highlight the acoustic characteristics of NT texts. It began in the 1990s as a co-initiative by Margaret E. Lee and Bernard B. Scott (1996; cf. Lee 1996), before Lee (2005) formalised the approach into the method expounded in her $\mathrm{PhD}$ dissertation. The method has grown in popularity since 2009, owing to Lee and Scott's co-written programmatic work Sound Mapping the New Testament (henceforth SMNT). ${ }^{3}$ In this book, Lee and Scott provide a step-by-step method for analysing the aural characteristics of Koine Greek prose compositions. Specifically, they call on scholars to create "sound maps" $" 4$ that illuminate different acoustic features that are not obvious when texts are read silently.

The starting point of sound mapping is the delineation of the structuring units called côla [sg.: $\kappa \omega ́ \lambda \mathrm{ov}$ ] and periods [sg.: $\pi \varepsilon \rho i ́ o \delta o \varsigma]$, which are understood to refer to the theory of structuration formalised in the Graeco-Latin rhetorical tradition. This theory of structuration is not to be confused with dispositio: while the latter deals with the organisation of arguments, and is thus mainly concerned with the overall structure of discourses (macro-structure), the former deals with the arrangement of words, and is thus closely related to style (elocutio) and micro-structure. ${ }^{5}$ Concretely, when developing sound maps, each côlon is numerated and placed on its own line, and each period is made to correspond to a paragraph: we can therefore speak of a "colometric presentation." Different kinds of acoustic features-such as sound repetitions, hiatus and consonant clashes ${ }^{7}$ - are then marked by means of highlighting, bold typeface, colours, etcetera, which eventually yield a sound map for a specific passage. Such a

\footnotetext{
${ }^{2}$ Some scholars even perform the texts themselves in order to observe the reactions of the hearers; so, e.g., Boomershine (2014); Rhoads (2016).

3 Among the scholars engaged in sound mapping, we can mention Brickle (2012), Boomershine (2015); De Waal (2015); and Nässelqvist (2015). See also the series of articles collected by Lee (2018b).

4 "Sound map" is defined as "a visual display that exhibits a literary composition's organisation by highlighting its acoustic features and in doing so depicts aspects of a composition's sounded character in preparation for analysis" (Lee and Scott 2009, 168).

${ }^{5}$ On côla and periods, see Aristotle, Rhet. III, 8-9; Pseudo-Demetrius, Eloc. 1-35; Rhet. Her. 4.19; Cicero, Or. Brut. 204-226; Quintilian, Inst. 9.4.126-130; Alexander, Fig. 27-28; Pseudo-Aelius Aristides, Pol. 507-508. The notions of côlon and period are still little known in the field of biblical studies. For an initial engagement with these notions, see Lausberg (1973); cf. Dräger (1998a; 1998b; 2003); cf. also Anderson (2000, 94-101).

${ }^{6}$ The idea of presenting the NT writings colometrically is not new. In the $1920 \mathrm{~s}$, some scholars already suggested that the NT should be edited in côla and periods as a means to highlight its oral dimension: so, e.g., Schütz (1922a); Debrunner (1926); Kleist $(1927$; 1928). Colometric translations have even been published for some NT books: Schütz (1922b; 1928); Woerner (1922; 1924). Note that the term "colometry" is also used by codicologists to refer to the layout found in some ancient manuscripts, e.g., Bezae, Claromontanus, Coislinianus, Amiatinus, where the text is disposed in sense lines. In this case, "colometry" is opposed to the more widespread system of "stichometry" (Thompson 1912, 67-71; Metzger 1981, 39-40; Mathisen 2008, 155-157). However, it remains difficult to prove that such "sense lines" fully correspond to the côla described by the ancient rhetoricians.

7 "Consonant clashes" are when specific consonants are combined and create an unpleasant effect; see, e.g., Dionysius of Halicarnassus, Comp. 22.14-44.
} 
sound map is then used as a complementary tool for exegesis. ${ }^{8}$ The whole approach is designed to be as historically informed as possible, with the aim of using "emic" criteria that are based on the data provided in ancient rhetorical treatises. These include Aristotle's Rhetoric, Pseudo-Demetrius's On Style, Cicero's Orator, Dionysius of Halicarnassus's On Literary Composition, Quintilian's The Orator's Education, and so on.

The idea behind sound mapping is certainly appealing, as are the different ways the method has been applied in the past decade. Following Lee and Scott's pioneering work, many scholars have used their method when analysing different passages from the NT, including the prologue of 1 John (Brickle 2012), the passion narrative in the Gospel of Mark (Boomershine 2015), the four first chapters of the Gospel of John (Nässelqvist 2015), some chapters of Revelation (Waal 2015), as well as extracts of the Pauline Letters (Livesey 2012; Oestreich 2018). Scholars who have applied this method have looked for points of emphasis created by sound repetitions, the presence of hiatus and consonant clashes, or the strategic placement of words either at the beginning or at the end of côla and periods. ${ }^{9}$ They have further challenged the traditional delimitations of passages (Lee and Scott 2009, e.g., 211-216), addressed issues of textual criticism (Livesey 2012), and also discussed traditional punctuation choices (Nässelqvist 2018a; Marschall 2020). We should note that, with the exception of Dan Nässelqvist (see point 2.2 below), most scholars who apply sound mapping have adopted Lee and Scott's method without discussing further the criteria for delineating côla and periods. They therefore do not offer any additional investigation into the rhetorical treatises themselves. Yet, as I will argue, there are some significant limitations to this initial version of sound mapping, especially in its first and second steps (i.e., in the criteria used to delineate respectively côla and periods). In fact, several of Lee and Scott's assertions do not correspond well to the data found in the ancient sources, such that a fresh assessment of the method they propose is warranted.

This article is an appeal to scholars to develop sound mapping further, not in terms of its exegetical approach-I will not propose new ways of applying the methodbut rather in terms of honing the method itself. Of course, when a new approach is emerging, it is tempting to explore all the potential implications it may hold for exegesis. However, it is also necessary to ensure that this new approach possesses a solid methodological foundation. In the case of sound mapping, which claims to be a historico-rhetorical approach, it is especially crucial that we ensure that the criteria we use for côla and periods delineation accurately reflect the data found in the ancient sources; otherwise, scholars risk producing sounds maps whose structure has little to do with the ancient conventions of structuring prose texts.

\footnotetext{
8 "Sound mapping is not a subsitute for exegesis but it lays a foundation. Exegesis that ignores sounds, ignores clues to interpretation" (Lee and Scott 2009, 268).

${ }^{9}$ Nässelqvist $(2015,125-26)$ has offered a theory of how to identify the places that receive special emphasis, using the concept of "aural intensity."
} 


\section{Guidelines and Criteria Currently Used in Sound Mapping}

\subsection{E. Lee and B. B. Scott (2009)}

In $S M N T$, Lee and Scott propose guidelines for delineating côla and periods. The term "guidelines" is appropriate here, as they do not provide a series of binding criteria: they rather give a few indications that might guide the process of analysis. Beginning with the côlon, they indicate that it "is the basic building block of analysis because it represents a breath unit, a unit of speech" (Lee and Scott 2009, 169). Hence, côla span sense units. Lee and Scott (2009) also provide some guidance in terms of syntax:

Sometimes a colon can be identified as a predicate and all of its related elements ... In compositions with complex syntax and multiple levels of grammatical subordination, colometric boundaries frequently circumscribe a sense unit controlled by a finite verb or some other verbal element, such as a participle or infinitive ... Sometimes no verbal element is present, but Eivvar is implied ... At other times, the verbal element is implied elliptically in parallel côla ... Conversely, sometimes a colon contains more than one finite verb. This frequently occurs with brief cola and compound predicates ... (pp. 169-170) ${ }^{10}$

In the numerous examples of sound maps that are given in the second part of SMNT, we can observe the following tendencies. Most of the côla correspond to what modern syntax would term "clauses," either independent or dependent. We also find some cases where a single côlon encompasses many clauses. In the case of direct speech, it also happens that single words are considered côla. ${ }^{11}$ As to their length, this varies greatly: côla identified by Lee and Scott typically have between 7 and 25 syllables; however, there are also shorter côla (from 3 syllables) and sometimes much longer ones (up to around 50 syllables). ${ }^{12}$

As a second step towards colometric presentation, Lee and Scott $(2009,171)$ propose ways for grouping côla into periods. They indicate that "côla can be combined paratactically or by means of grammatical subordination." In other words, periods roughly correspond to complex sentences. They also claim that "all prose can be understood to consist of periods"; however, style can be more or less "periodic" (ibid., 179-180). To put it another way, they distinguish different kinds of periods, indicating that "well-rounded and balanced periods could be distinguished from those that merely

\footnotetext{
${ }^{10}$ Lee (2018a, 17-18) clarifies that these indications are not exhaustive, but rather serve as a "rule of thumb."

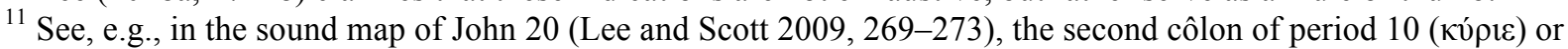
the second côlon of period 11 (Mapía).

${ }^{12}$ Examples of very short côla are frequently attested, notably in the sound map of John 20 (Lee and Scott 2009,

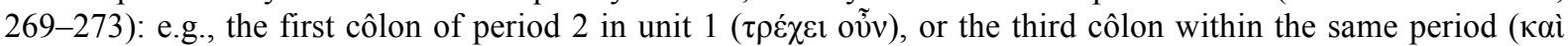

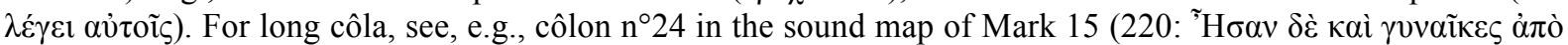

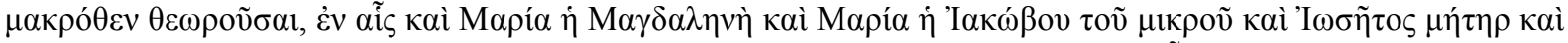

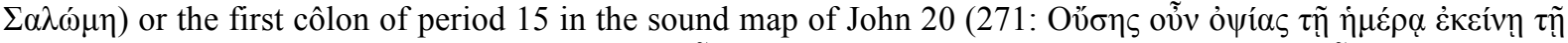

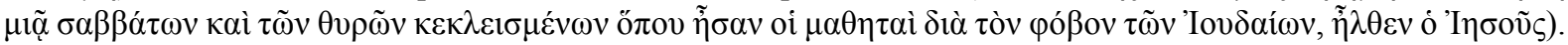


met certain minimal technical requirements" (ibid.). If we refer to the connotation of $\pi \varepsilon p i ́ o \delta$ o $\varsigma$ as a "way around" or a "circular path," some periods can be said to be "highly periodic" while others are "less periodic" (ibid., 110; cf. 180). Concretely, "wellformed" periods typically exhibit rounding (sounds at the end of the period that echo sounds at the beginning), balance (parallel or antithetic côla), or elongation (the final côlon is longer than those that precede it and/or ends with multiple long vowels) (ibid., 171). When such sophisticated periods follow one another, the style of composition can be qualified as "periodic." At the other extreme, some periods simply consist of a set of côla which together express a thought. ${ }^{13}$ When such periods succeed one another, they form a "continuous style" (ibid., 180-181).

In sum, whereas all prose consists of periods, the way côla are combined draws a distinction between periodic style, made of "well-formed" periods, and continuous style, made of less-sophisticated periods. As to the length of periods, it is clear from a mere glance at the multiple sound maps found in SMNT that these typically have between 2 and 5 côla.

\subsection{Nässelqvist (2015)}

As far as I am aware, the only person who has so far seriously challenged Lee and Scott's method is Dan Nässelqvist. In his $\mathrm{PhD}$ dissertation published in 2015, he points to certain deficiencies in the initial method of sound mapping and proposes a new version of it, one which includes more precise criteria for delineating côla and periods (Nässelqvist 2015, 126-140). His remarks fall into two categories: those that discuss the length of côla and those that address the concept of the period.

Regarding côla, Nässelqvist suggests that we should add to Lee and Scott's model the criterion of length. Indeed, as he argues, the fact that côla are breath units - that is, meant to be uttered without internal respiration - has an effect on their length: basically, côla should be neither too short nor too long. ${ }^{14}$ Based on the recommendations of rhetoricians and his study of many examples found in the treatises, Nässelqvist (2015, 129) distinguishes between standard (9-23 syllables) and acceptable lengths (7-30 syllables). This represents a significant clarification when compared to Lee and Scott's guidelines that may have a significant impact on the choice of delineation. Connected to Nässelqvist's view on the minimum length of côla is his notion of comma [кó $\mu \mu \alpha]$. This refers to a third unit described in the treatises, in addition to the côlon and the period; the term "comma," however, occurs more rarely. In SMNT, Lee and Scott described the comma as nothing more than a short côlon, and the term does not appear in their analyses. In contrast, Nässelqvist argues that the difference between commata and côla is not only a matter of length, but also of nature and prosody. Specifically, he

\footnotetext{
${ }^{13}$ Lee and Scott $(2009,172)$ suggest that even those periods are easily identified.

${ }^{14}$ Cf. Aristotle, Rhet. 3.9.6; Pseudo-Demetrius, Eloc. 4; Quintilian, Inst. 9.4.125.
} 
suggests that commata, unlike côla, do not always contain a verbal form (ibid., 132). Also, he argues that commata cannot stand alone as a breath unit because of their shortness: as a result, many commata should be grouped together to form a côlon of acceptable length; or, alternatively, a comma should sometimes be joined with a côlon (ibid., 132-133). In other words, Nässelqvist considers the comma to be a subpart of the côlon.

When it comes to periods, Nässelqvist significantly challenges Lee and Scott's observations. He describes the period as an artistic arrangement of côla, indicating that periods are more codified than our modern sentences. Specifically, the difference "lies in the sophisticated composition of the period" (Nässelqvist 2015, 125). Hence, in the process of sound mapping, only those côla that have specific characteristics should be grouped into periods. Other côla belong to "continuous style": in this alternative style, Nässelqvist (ibid., 138-139) explains, côla are simply juxtaposed, without any periodic contour. As typical features of periods, he mentions elongation (long final côlon), hyperbaton ("abnormal word order, in which an essential idea is left suspended until the end of the sentence" [Fowler 1982, 98 n. 41]), ${ }^{15}$ and symmetry (sound echoes, antithesis, similarity in length). Nässelqvist (2015, 134-138) also suggests that periods should exhibit a "well-turned ending."

\section{Sound Mapping in Light of Ancient Sources: Some Issues to Be Re-examined}

Moving on to consider the data from the rhetorical treatises, I will now point out some elements that seem problematic in the guidelines and criteria proposed by Lee and Scott and Nässelqvist respectively. In my view, the four following issues should be reexamined: the definition of the period; the notion of non-periodic style; the syntactic nature of côla; and the length of côla. ${ }^{16}$

\subsection{The definition of the period}

What is a period in ancient rhetoric? Is it only a combination of côla, as Lee and Scott suggest? Or is it rather an artistic arrangement of côla that ensures a well-turned ending, as Nässelqvist argues? I contend that the answer stands somewhere in between. Nässelqvist is perfectly right to stress that not all côla should be grouped into periods. In fact, ancient rhetoricians clearly distinguish two kinds of styles. These are the "interwoven" style, which is composed of periods, and the "disjointed" or "continuous"

\footnotetext{
${ }^{15}$ On the structuring role of hyperbaton in Greek prose, see Markovik (2006).

16 The discussion below is based upon the following treatises: Aristotle, Rhet. III; Pseudo-Demetrius, Eloc.; Rhet. Her.; Cicero, Or. Brut.; Id., De or. III; Dionysius of Halicarnassus, Comp.; Quintilian, Inst. VIII, IX and XI; Alexander, Fig.; Pseudo-Aelius Aristides, Pol., Pseudo-Herodian, Fig., Hermogenes, Id.
} 
style, which contains no periods. ${ }^{17}$ However, Nässelqvist arguably works with a conception of the period that is too restrictive. Of course, côla that are part of a period are often linked by means of hyperbaton, gorgianic figures (antithesis, paromoiosis, parisosis), ${ }^{18}$ and so on. The three sayings below are thus typical periods (the lettering indicates the côla):

\section{Example 1}

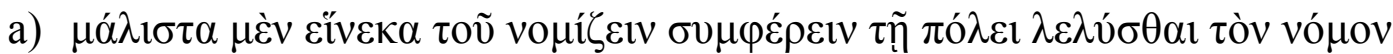

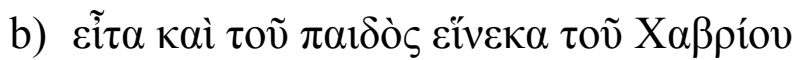

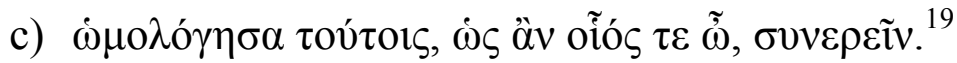

\section{Example 2}

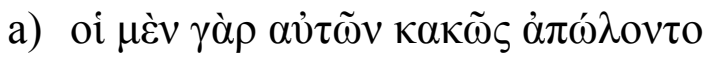

b) oi $\delta$ ' $\alpha i \sigma \chi \rho \tilde{\omega} \varsigma \dot{\varepsilon} \sigma \omega ́ \theta \eta \sigma \alpha v^{20}$

\section{Example 3}

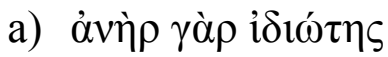

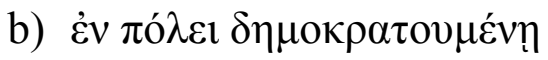

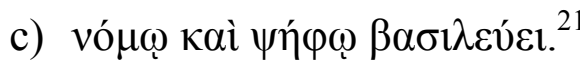

Examples of such sophisticated periods are also found in the NT. In Luke's Gospel, we can mention, for instance, its long opening sentence, which can be analysed as a fourcôla period:

\footnotetext{
${ }^{17}$ The term "continuous" is a possible translation of Aristotle's $\varepsilon i p o \mu \varepsilon \dot{v} \eta \lambda \dot{\varepsilon} \xi 1 \zeta$ (Rhet. 3.9), while "disjointed" refers

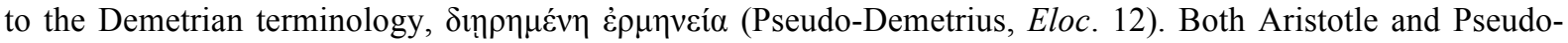
Demetrius use the term $\kappa \alpha \tau \varepsilon \sigma \tau \rho \alpha \mu \mu \varepsilon \dot{v} \eta$ ("interwoven") to refer to periodic style.

${ }^{18}$ Antithesis is to be understood in a broad sense as comprising not only opposition in terms of content but also opposition in terms of form. Parisosis consists of the equality or approximate equality of côla. Paromoiosis designates similarities in sound that usually occur at the extremities of côla. On these figures, see, e.g., Aristotle, Rhet. 3.9; Pseudo-Demetrius, Eloc. 22-29. These three figures are usually designated as "gorgianic" because of their association with the sophist philosopher and rhetorician Gorgias (5th-4th centuries BCE); on the origin of this attribution, see Noël (1999).

19 "a) Chiefly because I thought it was in the interest of the state for the law to be repealed / b) but also for the sake of Chabrias' boy / c) I have agreed to speak to the best of my ability in their support" (Pseudo-Demetrius, Eloc. 10 [trans. Innes, LCL]; the extract is from Demosthenes, Lept. 1). The division into three côla is made explicit by Pseudo-Demetrius.

20 "a) For some of them perished miserably / b) others saved themselves disgracefully" (Aristotle, Rhet. 3.9.7 [trans. Kennedy]; the extract is from Isocrates, Paneg. 149).

21 "a) A member of the common people / b) in a democratic city / c) is a king by virtue of the law and his own vote" (Alexander, Fig. 27.19-20 [my translation]; the extract is from Aeschines, Ctes. 233). The division is made explicit by Alexander himself (Fig. 28.9-12).
} 
Example 4 (Luke 1:1-4) $)^{22}$

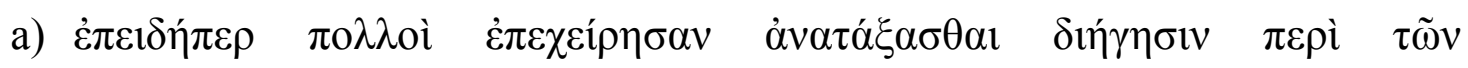
$\pi \varepsilon \pi \lambda \eta \rho о \varphi о \rho \eta \mu \varepsilon ́ v \omega v ~ \dot{\varepsilon} v \dot{\eta} \mu \tilde{i} v \pi \rho \alpha \gamma \mu \alpha \dot{\tau} \omega v$

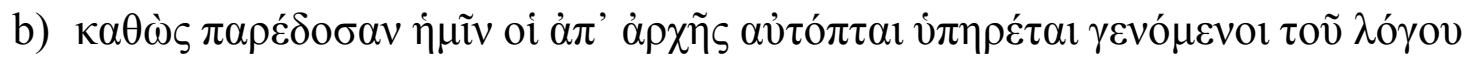

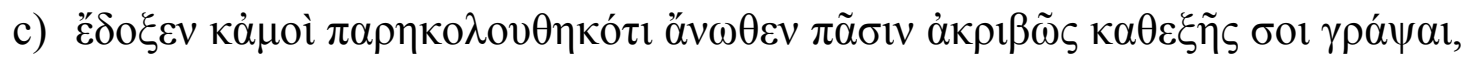

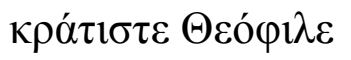

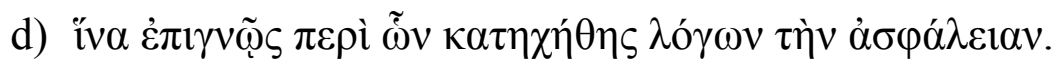

In Pauline letters, periods often exhibit gorgianic figures. For example, Rom 2:12-13 contains two periods, both of which are built on antitheses. In the first period, which is made of four côla, we can also observe parisosis - the respective length of côla being 9 , 8, 9, and 7 syllables - and paromoiosis - the end of the third côlon echoes the end of the

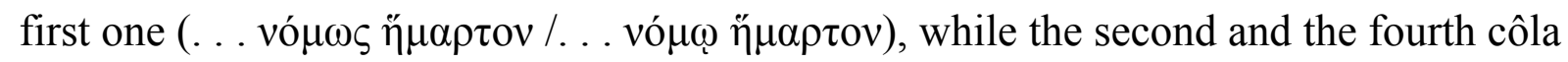

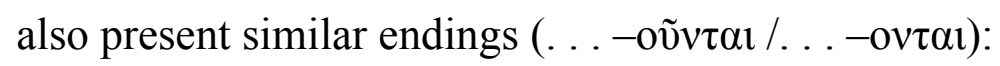

Example 5 (Rom 2:12-13) ${ }^{23}$

Period 1

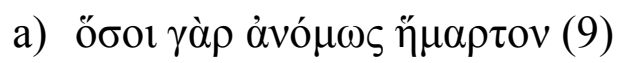

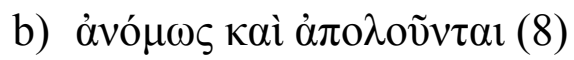

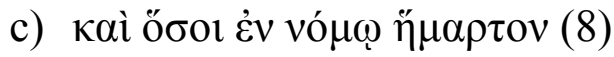

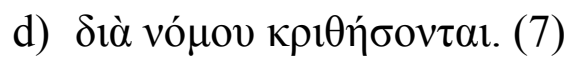

\section{Period 2}

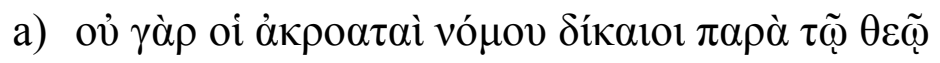

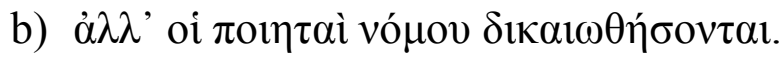

Nevertheless, a close look at the examples from the treatises reveals that the concept of period is in fact highly flexible, even though it is more codified than the modern concept of the sentence. Not all periods consist of sophisticated arrangements of côla. Concretely, côla can also be linked in a looser way, that is, without figures and without a well-turned ending. For example, the opening of Plato's Republic is explicitly

\footnotetext{
22 “a) Inasmuch as many have undertaken to compile an account of the things accomplished among us b) just as they were handed down to us by those who from the beginning were eyewitnesses and servants of the word c) it seemed fitting for me as well, having investigated everything carefully from the beginning, to write it out for you in consecutive order, most excellent Theophilus d) so that you may know the exact truth about the things you have been taught." (NASB)

23 “a) For all who have sinned without the Law b) will also perish without the Law c) and all who have sinned under the Law d) will be judged by the Law. a) For it is not the hearers of the Law who are just before God b) but the doers of the Law will be justified." (NASB)
} 
described as a period by Pseudo-Demetrius, even though it lacks the typical periodic features:

\section{Example 6}

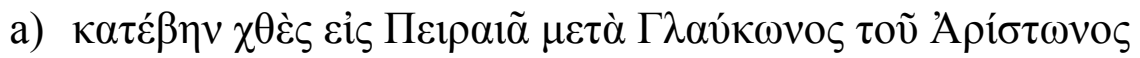

b) $\pi \rho \circ \sigma \varepsilon v \xi o ́ \mu \varepsilon v o ́ \varsigma \tau \varepsilon \tau \tilde{n} \theta \varepsilon \tilde{\omega}$

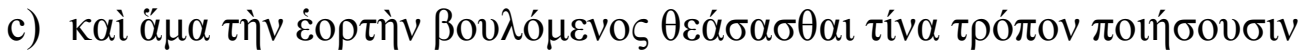

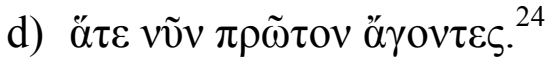

It is worth detailing the context in which this example is given: it is found in a typology of periods, in which Pseudo-Demetrius distinguishes between three categories: the rhetorical period, the historical period, and the dialogue period. These three types can be classified according to their degree of periodicity or "circularity," that is, depending on whether their shape recalls more or less the perfection of a circle. ${ }^{25}$ Specifically, the rhetorical period has a "circular shape," 26 thus representing the period par excellence: it is well-structured and its ending is underlined by hyperbaton or a rhythmical pattern. As a model, Pseudo-Demetrius provides an extract of Demosthenes's Against Leptines (see above, example 1). At the other extreme, the dialogue period is said to be "loose and simple to the point that it scarcely shows that it is a period." 27 Example 6 above (an extract of Plato's Republic) is an instance of this non-circular period. Pseudo-Demetrius explains that this period is composed in a style that is quite disjointed - that is, it is close to non-periodic style. ${ }^{28}$ In other words, it is considered a period despite being atypical. Finally, the narrative period "should neither be too carefully rounded nor too loose,"29 being situated between the rhetorical and the dialogue periods. Such a classification of periods according to their "degree of circularity" is not specific to Pseudo-Demetrius: similar conceptions can be observed at least in Dionysius of Halicarnassus and also in Quintilian. $^{30}$

To sum up, it appears that the concept of the period is more codified than Lee and Scott argue (in "continuous style," côla are not linked to form periodic structures),

\footnotetext{
24 "I went down yesterday to the Piraeus with Glaucon, the son of Ariston / in order to offer up my prayers to the goddess / and also because I wanted to see how they would organise the festival / as they were celebrating it for the first time" (Pseudo-Demetrius, Eloc. 21 [my translation]; the extract is from Plato, Rep. 1.1). Pseudo-Demetrius quotes only the beginning and the end of this period; the division into côla is mine and might not correspond to what Pseudo-Demetrius had in mind.

${ }^{25}$ This alludes to the very meaning of $\pi \varepsilon \rho$ ío $\delta$ s (way around, circular path, circuit, circle). When they refer to periods, rhetoricians frequently make use of the metaphors of a circle or a circular race: see, e.g., PseudoDemetrius, Eloc. 11; 19-21; Cicero, Or. Brut. 204; 207; Dionysius of Halicarnassus, Comp. 22.5; 23.22; Alexander, Fig. 27.17-22.

${ }^{26}$ Eloc. 20.

27 Eloc. 21.

28 Eloc. 21.

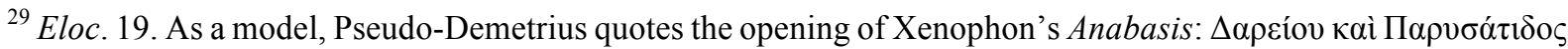

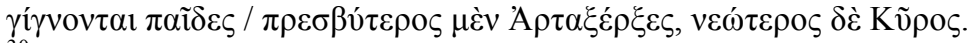

${ }^{30}$ Dionysius of Halicarnassus, Comp. 22.5; Quintilian, Inst. 9.4.127.
} 
but is more flexible than Nässelqvist suggests (the pattern of the well-turned ending is typical, but not necessary ${ }^{31}$ ). Hence, the challenge is to establish the limit of periodic and non-periodic styles, that is, what are the minimal characteristics that a set of côla need to exhibit in order to form a period?

\subsection{Disjointed style and autonomous côla}

If the boundaries of periodic style are difficult to define, clarification might perhaps be found in the syntactic characteristics of non-periodic style. Examples of this "disjointed" style are less frequent in the treatises: ancient rhetoricians indeed focus on periods, which are the foundation of most figures of speech and therefore deserve a longer discussion. Nevertheless, a glance at some examples suggests that when non-periodic style is used, each côlon has sufficient syntactic autonomy to stand alone, much like a short sentence. In the two sayings below, each côlon is punctuated with a final point:

\section{Example 7}

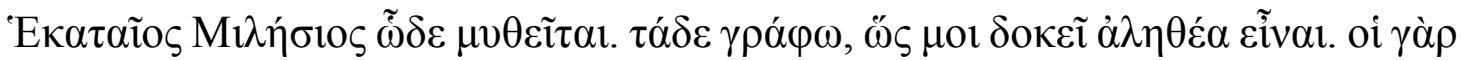

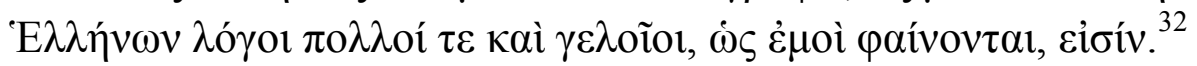

\section{Example 8}

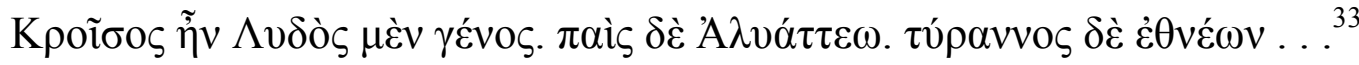

Of course, this does not mean that modern analysis would always consider non-periodic côla as short sentences, but only that those côla can be considered as independent sentences in accordance with our modern habits. Due to this syntactic characteristic, such côla might be termed "autonomous." This is perfectly in line with PseudoDemetrius's description:

Sometimes the côlon forms a complete thought in itself, as for example when Hecataeus opens his "History" with the words "Hecataeus of Miletus thus

\footnotetext{
${ }^{31}$ Concerning this point, it seems that Nässelqvist $(2015,134)$ was influenced by his understanding of the period's definition provided in Pseudo-Demetrius, Eloc. 10: "a combination of cola and commata which has brought the underlying thought to a conclusion with a well-turned ending" (italics are mine). Cf. a close translation in the edition established by Innes $(1995,351)$. However, this is not the only possible understanding, and arguably not

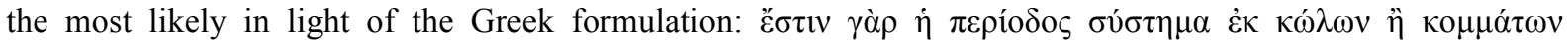

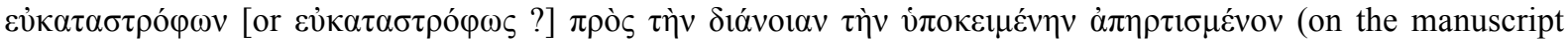
tradition, see Chiron [1993, CVII-CXXXV]). Specifically, the presence of $\pi \rho$ ó $\varsigma$ suggests that the verb $\dot{\alpha} \pi \alpha \rho \tau i ́ \zeta \omega$ means in this context "square with smth" or "fits perfectly smth," rather than "conclude smth" or "bring smth to an end." In other words, the system of côla and commata "perfectly squares with the underlying thought."

32 "Hecataeus of Miletus thus relates. I write these things as they seem to me to be true. For the tales told by the Greeks are, as it appears to me, many and absurd" (quoted by Pseudo-Demetrius in Eloc. 12 [trans. Innes, LCL]). The last côlon is arguably a monocôlon period (cf. Eloc. 17).

33 "Croesus was a Lydian by birth. He was the son of Alyattes. He ruled the nations ..." (Herodotus, Hist. 1.6.1; quoted by Hermogenes, Id. 1.3.12 [my translation]).
} 


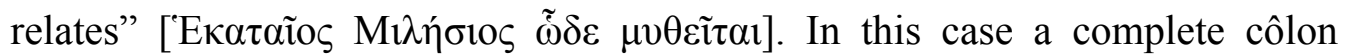
coincides with a complete thought and both end together. ${ }^{34}$

That this description alludes to the côla of disjointed style is made explicit later in the treatise, where Pseudo-Demetrius again quotes the opening of Hecataeus's Genealogies as a model of this style. ${ }^{35}$ I therefore suggest that syntactic completeness should be considered a criterion for delineating non-periodic côla. To be clear, this is a necessary criterion, not a sufficient one: in fact, it sometimes happens that the côla of periodic style also present syntactic completeness. ${ }^{36}$ Yet, such a criterion still helps clarify the boundary between periodic and non-periodic styles. Let us take an example from the parable of the good shepherd.

Example 9 (John 10:4)

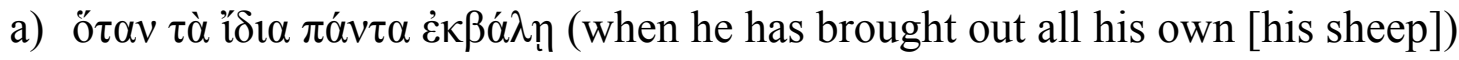

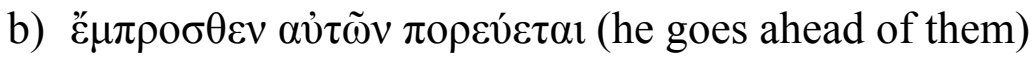

Nässelqvist $(2015,151)$ considers this saying to belong to non-periodic style. Indeed, according to his strict definition of periods, there are not enough elements to group these two côla. In contrast, I would rather suggest that we have here a clear example of a period. Indeed, the first côlon ("when he has brought out all his own") cannot stand on its own as an independent sentence: it is subordinated to what follows, the main clause corresponding to the second côlon ("he goes ahead of them"). Assuming that the

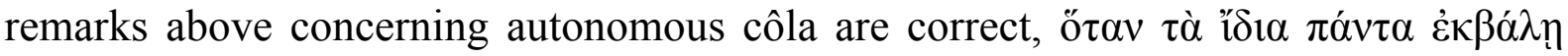
should thus not be seen as belonging to disjointed style, but rather as being part of a

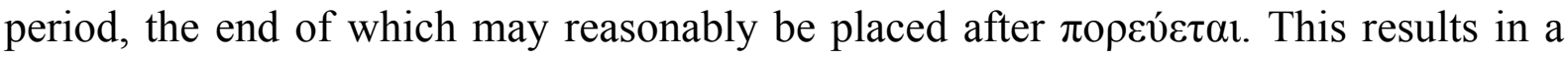
short period, well-balanced with its two côla of equal length (10 and 9 syllables), and

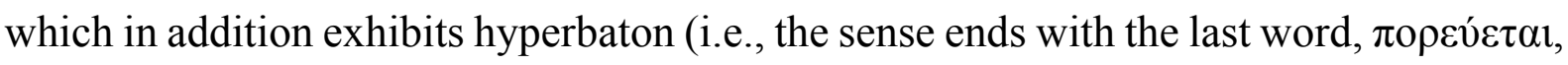
which is the main verb).

\subsection{The syntactic nature of côla within periods}

This brings us to the difficult issue of the syntactic nature of côla within periods. According to the guidelines typically used in sound mapping, the key element seems to be the presence of at least one verb, which may or may not be finite and may also be implied. Nässelqvist (2015, 132; cf. 142) formulates a strict correspondence between the côlon and the modern concept of the clause, ${ }^{37}$ while Lee and Scott's formulation

\footnotetext{
${ }^{34}$ Eloc. 2 (trans. Innes, LCL, slightly modified).

35 Eloc. 12.

${ }^{36}$ See an example in Pseudo-Demetrius, Eloc. 3; cf. Eloc. 19.

37 "The colon is a sense unit, which means that it consists of an entire clause with at least one verbal form and its related elements" (Nässelqvist 2015, 132). Nässelqvist $(2015,133)$ also signals that two short clauses sometimes together form a single côlon.
} 
suggests a slightly broader conception (Lee and Scott 2009, 169-170; see further point 2.1 above). However, these descriptions are arguably too wooden to account for the flexibility of the notion as it appears in the ancient sources, regardless of the exact definition of "clause" that one adopts or the possibility that verbs are often implied. Indeed, it just so happens that phrases can be described as côla. Not only is this designation applied to those phrases that include a relative clause, and therefore might be considered "noun clauses," if we adopt a broad definition, or as "controlled by a verb," but also to noun phrases which consist simply of a noun associated with an adjective, as well as to prepositional phrases composed of a preposition, a noun and an adjective. This is clear from the two examples of periods below:

\section{Example 10}

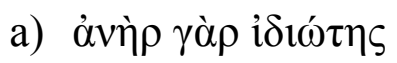

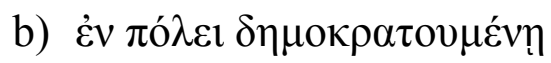

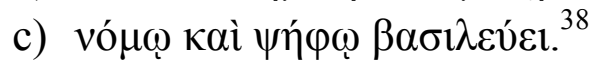

\section{Example 11}

a)

b) $\lambda o ́ \gamma \omega \kappa \alpha \lambda \tilde{\omega} \varsigma \dot{\rho} \eta \theta \dot{\varepsilon} v \tau \imath$

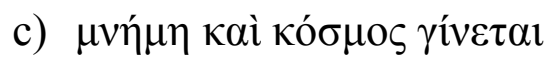

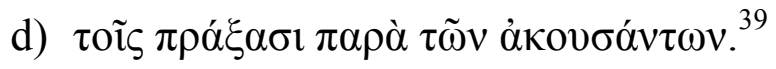

The first of these periods consists of a single clause. Only the last côlon is controlled by

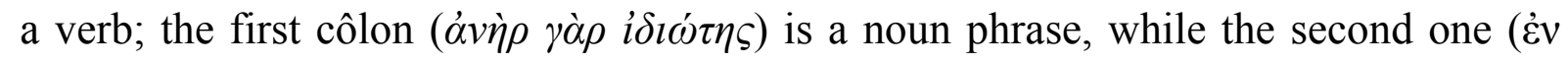

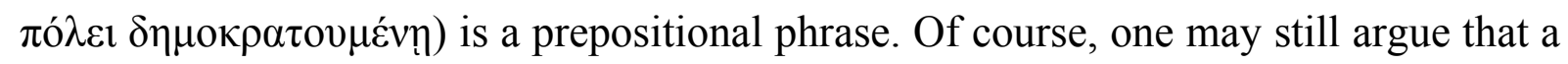
form of eijuí could be supplied in the first côlon, even if it would sound awkward, given the formulation. However, in the case of the second côlon it is difficult to argue that it consists of a clause or is controlled by a verb simply because of the presence of the participle $\delta \eta \mu о \kappa \rho \alpha \tau o v \mu \varepsilon ́ v \eta$, which acts here as an adjective. Then, in the second period, the three first côla are indeed clauses. As for the last côlon, however, we observe that it begins as a complement to the main clause that started in the third côlon. Formally, the

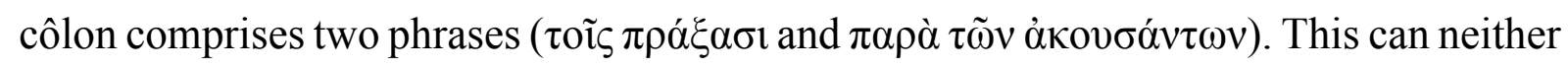
be considered a clause by supplying a verb, nor can it be seen as a unit controlled by two verbs ( $\pi \rho \alpha \dot{\xi} \xi \alpha \sigma \mathrm{l}$ and $\dot{\alpha} \kappa o v \sigma \alpha ́ v \tau \omega v)$, since these are substantives in this context. It should thus be recognised that, besides clauses and combinations of clauses, phrases and combinations of phrases can also constitute côla. Nevertheless, we may note that the

\footnotetext{
${ }^{38}$ For reference and translation, see n. 22 above.

39 “a) When deeds have been nobly done / b) then through speech finely uttered / c) there comes honour and remembrance / d) to the doers from the hearers" (Dionysius of Halicarnassus, Comp. 9.4 [trans. Usher, LCL]; the extract is from Plato, Menex., 236d). Dionysius identifies only the last côlon; yet his remark that the côla are equal (Comp. 9.5) leaves little room for doubt regarding the place of the other caesurae.
} 
phrases-côla mentioned in the treatises are generally qualified by one or more dependent(s). It seems that the presence of these dependents invests such phrases with enough semantico-syntactic completeness to allow them to stand on their own as côla, even in the absence of a verb.

All in all, the syntactic nature of periodic côla is more flexible than currently assumed by scholars involved in sound mapping. The key notion seems to be a certain degree of semantico-syntactic completeness, rather than the presence of a verb. As a result, phrases or a combination of phrases can also constitute côla, so long as these convey a "complete thought." Borrowing here from Thomas Habineck's $(1985,28)$ formulation, we can conclude that "almost any constituent can, under the right circumstances, be a côlon."

When it comes to delineating côla in the NT, such a flexible conception multiplies the analytical possibilities, and therefore tends to make the task more complex. Nevertheless, working with a flexible conception also allows us to bring more stylistic features to light. A good example is found in 2 Cor 10:1:

\section{Example 12}

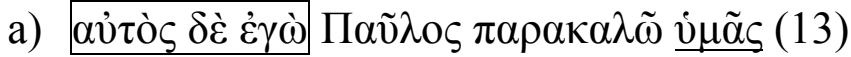

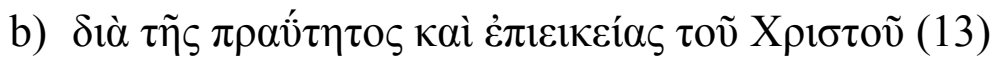

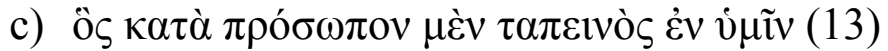

d) $\dot{\alpha} \pi \grave{\omega} v \delta \dot{\varepsilon} \theta \alpha \rho \rho \tilde{\omega} \varepsilon \dot{\varepsilon} \zeta \underline{\dot{j} \mu \alpha \tilde{\alpha}}$. (8)

We can observe the similarities in sound between the first and the last côlon: $\dot{\alpha} \pi \grave{\omega} v \delta \dot{\varepsilon}$

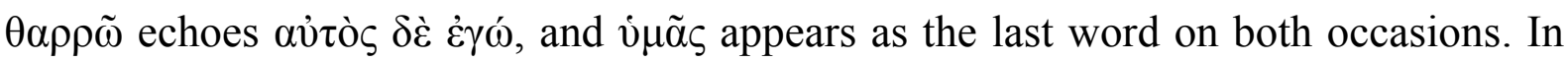
addition, the division above reveals that côla a), b) and c) have exactly the same length (13 syllables). In my view, this passage is a perfect example of a period. We should note that, in this disposition, côlon b) consists of a prepositional phrase. Should we rely on the definition of the côlon as a clause, we would have to group lines a) and b) into a single côlon, which would then make the sound echoes much less audible.

\subsection{The length of côla and the notion of comma}

Turning now to the question of the length of côla, Nässelqvist is certainly right to address this point and to define both standard and acceptable lengths as part of his analysis. I fully agree that we must determine an upper limit: some of the côla delineated by Lee and Scott are indeed far too long when compared to ancient reading habits, with some of the côla approaching 50 syllables. ${ }^{40}$ As to the maximum length of 30 syllables that Nässelqvist $(2015,129)$ proposes, this indeed accurately reflects the examples

\footnotetext{
${ }^{40}$ For examples, see n. 12 above.
} 
found in the treatises. ${ }^{41}$ However, the minimal length he suggests of 7 syllables is less convincing, and thus his claim that Lee and Scott delineate côla that are "too short" (Nässelqvist 2015, 130 n. 42) cannot be sustained. As far as I am aware, there is no basis in the treatises for such a lower limit. Conversely, there are examples of short côla that are less than 7 syllables. According to rhetoricians, such côla are not only acceptable but are welcome in specific contexts, for example when the subject is "small" or when the style is passionate. ${ }^{42}$ These short côla even receive a special name: commata in Greek, or incisa in Latin. Cicero compares their effect to stabs, an image also found in the Rhetoric for Herennius. ${ }^{43}$ A typical example from the NT is 2 Cor 11:21-27, of which vv. 21-22 are reproduced below:

\section{Example 13}

'Ev $\tilde{\omega} \delta$ ' $\ddot{\alpha} v \tau \iota \varsigma \tau \lambda \mu \tilde{\alpha}$

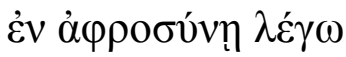

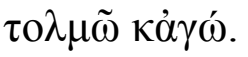

'Eßpaĩoí દioıv;

кỏyó.

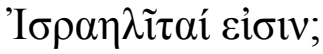

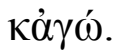

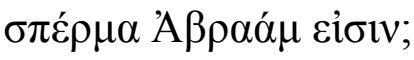

кờó.

In my view, the first three commata should be grouped into a short period, while the next ones function autonomously. ${ }^{44}$ The image of stabs is meaningful here: the usage of very short côla creates a vehement style that perfectly fits the content, where Paul harshly criticises his opponents in the Corinthian community for boasting about themselves.

This brings me to a final remark concerning Nässelqvist's description of the comma as being a subpart of the côlon. This description echoes a definition that does indeed seem to have circulated in antiquity, as attested in Cassius Longinus, Aquila Romanus, and also an allusion made by Quintilian. ${ }^{45}$ However, when one compares the definitions and examples from the different treatises, such a definition clearly fails to

\footnotetext{
${ }^{41}$ I would nevertheless extend this limit a little bit so that it goes up to 35 syllables (see the example of tetracoloi period in Pseudo-Herodian, Fig. 93.23-29; cf. Hemogenes, Id. 1.12.15).

${ }_{42}$ Pseudo-Demetrius, Eloc. 6-9.

${ }^{43}$ Cicero, Or. Brut. 224; Rhet. Her. 4.19.

${ }^{44}$ It is noteworthy that the delineation suggested above corresponds to that proposed by Augustine in the fourth book of his Doctrina Christiana (Doct. Chr. 4.7.12-13). Augustine indeed provides an analysis of 2 Cor 11:1630 in terms of membra $(=\kappa \tilde{\omega} \lambda \alpha)$, caesa $(\kappa o ́ \mu \mu \alpha \tau \alpha)$ and circuitus ( $\pi \varepsilon p i ́ \delta \delta o \imath)$. On the equivalence between the Greek and Latin terminologies, see Cicero, Or. Brut. 204; 208; 211; 223; cf. Augustine, Doct. Chr. 4.7.11.

${ }^{45}$ Longinus, Fragm. Rhet., fr. 48. 329-39; Aquila Romanus, Fig. 27.32-28.5; Quintilian, Inst. 9.4.122. On the origin of the term кó $\mu \mu \alpha$, see some suggestions in Fowler (1982, 96 n. 33).
} 
represent a "technical" standard. Most rhetoricians, including Quintilian, consider the comma to be nothing more than a short côlon, ${ }^{46}$ precisely because both côla and commata can stand on their own or take place within a period. As a result, there is no solid basis for grouping many commata within a côlon.

\section{Conclusion: Looking for Appropriate Criteria between "Too Vague" and "Too Restrictive"}

As the studies published in the past ten years have proven, sound mapping provides a fresh approach to NT exegesis that can be applied in various ways. However, the foundations of the method - that is, the first and second steps, consisting of côla and period delineation respectively-remain hampered by several limitations. As the above analysis has demonstrated, both the guidelines proposed by Lee and Scott and the set of criteria established by Nässelqvist do not accurately reflect the data found in the ancient sources. These guidelines and criteria are too vague to be efficient, while some of them are also too restrictive to be of use. Furthermore, certain descriptions provided by Lee and Scott and Nässelqvist even conflict with the data from the rhetorical treatises: this is the case with the distinction between periodic and disjointed style, the definition of the period, the length of côla and the concept of comma, as well as the syntactic nature of côla. It is therefore necessary to reconsider the criteria for côla and periods delineation by further investigating the rhetorical treatises.

The need for more precise criteria has been recognised by Lee herself. In her introductory article to Sound Matters, a collective book she edited in 2018, she states: "We still need more specific criteria for delineating cola and methods for analysing how cola are combined" (Lee 2018a, 18). However, she also suggests that such a task is complicated because the data from the treatises are insufficient: "The problem resides in our sources ... Our ancient sources fail to provide more specific criteria for period and colon delineation ..." (Lee 2018a, 17-18). This idea is reminiscent of James A. Kleist's (1922b, 26-27) remark, made almost one century ago, that "in view of this lack of more precise information from ancient sources we are justified in allowing ourselves a certain latitude in applying the colometric system to ancient texts."

My view, by contrast, is less pessimistic. The ancient sources are not as unclear as one might assume, at least when they are considered as a group and analysed carefully. The least one can say is that the rhetorical treatises provide substantial data on the topic of colometry: there are not only definitions associated with models, which represent ideal côla, commata and periods, but also different kinds of recommendations, and last but not least, numerous extracts of classical literature which are commented on in terms of their colometric structure. Taken together, all these data permit us to get a

\footnotetext{
${ }^{46}$ See, e.g., Pseudo-Demetrius, Eloc. 9; Dionysius of Halicarnassus, Comp. 26.1; Quintilian, Inst. 9.4.122; Hermogenes, Id. 1.3.17.
} 
precise, though imperfect, understanding of what côla, commata and periods were in the mind of ancient rhetoricians. In addition, it is worth mentioning that such data come from more than ten different treatises spread over many centuries, which even enables us to evaluate the stability of the theories, as well as to grasp the specificities of each rhetorician. As regards the choice of treatises, it would be fruitful to integrate also slightly later treatises that are not taken into account in Lee and Scott's and Nässelqvist's studies, such as Alexander's On Figures, Hermogenes's On Types of Style, or Aelius Aristides's On Political Discourse. These three treatises arguably all date to the second or perhaps the turn of the third century $\mathrm{CE}$, meaning that they are still temporally quite close to the composition of the NT writings.

Nevertheless, we must also recognise that the notions of côlon, comma and period remain difficult to grasp. When reading the treatises, it is striking just how flexible these units can be. For example, some côla comprise only a few syllables, while others have nearly 30 syllables; côla usually contain a verb, but this is not always the case; periods often exhibit figures like hyperbaton, antithesis, balanced côla (parisosis) or sound echoes (paromoiosis), but this is also not uniform; and so on. This highly flexible character is precisely what makes it so difficult to describe these notions in an appropriate way. To be clear, flexibility is not to be confused with vagueness: if the notions of côlon, comma and period seem vague to us, this is merely because we no longer share the conventions of reading aloud and hearing texts that were in use in Graeco-Roman antiquity. Hence, the real challenge for the future development of sound mapping will be to formulate a set of criteria for côla and period delineation that are precise enough to be efficient when used by modern exegetes, yet not too restrictive, so as to respect the flexibility that appears in the treatises. When pursuing this challenge, it is clear that we need to mobilise all the possible elements that are signalled by rhetoricians themselves (length, figures, prosody ${ }^{47}$ rhythm $^{48}$ ) or that we can observe using modern linguistic theories (e.g., syntactic nature of côla, the role of particles ${ }^{49}$ ). Of course, the resulting set of criteria will never be fully satisfying. We will never be able to perfectly reproduce the colometric analysis that ancient readers would have made. Yet, as this article aimed at demonstrating, a close examination of the data from the ancient rhetorical treatises allows us to get a deeper understanding of the ancient system of colometry, which is already a good start towards establishing a more historically informed set of criteria for delineating côla and periods.

\footnotetext{
${ }^{47}$ Concerning the prosodic realisation of côla, commata and periods, see esp. Quintilian, Inst. 11.3.33-39; see also Aristotle, Rhet. 3.9.5; Pseudo-Demetrius, Eloc. 1; Cicero, De or. 3.182-182; 191; Augustine, Doctr. Chr. 4.7.11. $\mathrm{Cf}$. the attempt to apply modern prosodic phonology theories to ancient Greek in Scheppers $(2011 ; 2018)$.

${ }^{48}$ See, e.g., Aristotle, Rhet. 3.8; Pseudo-Demetrius, Eloc. 38-43; Cicero, Or. Brut. 212-226.

${ }^{49}$ On the role of particles in signalling the beginning of "côla," see the major work of Fraenkel (1965); on the link between Fraenkel's "kolon" and the ancient notion of côlon, see Habineck (1985).
} 


\section{Bibliography}

Anderson, R. Dean Jr. 2000. Glossary of Greek Rhetorical Terms Connected to Methods of Argumentation, Figures and Tropes from Anaximenes to Quintilian. Leuven: Peeters.

Boomershine, Thomas E. 2014. The Messiah of Peace: Mark 14-16 told in Greek by Dr. Tom Boomershine. Online: http://www.youtube.com/watch?v=3dwo3z9T7HY. . 2015. The Messiah of Peace: A Performance-Criticism Commentary on Mark's PassionResurrection Narrative. Eugene: Cascade.

Brickle, Jeffrey E. 2012. Aural Design and Coherence in the Prologue of First John. London: T\&T Clark.

Debrunner, Albert. 1926. Grundsätzliches über Kolometrie im Neuen Testament. TBI 5:231-233.

De Waal, Kayle B. 2015. An Aural-Performance Analysis of Revelation 1 and 11. New York: Lang.

Dräger, Paul. 1998a. Kolon. Historisches Wörterbuch der Rhetorik 4: col. 1138-1151. Edited by G. Ueding. Tübingen: Niemeyer; Berlin: de Gruyter.

.1998b. Komma. Historisches Wörterbuch der Rhetorik 4: col. 1176-1179. Edited by G. Ueding. Tübingen: Niemeyer; Berlin: de Gruyter.

.2003. Periode. Historisches Wörterbuch der Rhetorik 6: col. 750-764. Edited by G. Ueding. Tübingen: Niemeyer; Berlin: de Gruyter.

Fowler, R. L. 1982. Aristotle on the Period. CQ 32(1):89-99.

Fraenkel, Eduard. 1965. Noch einmal Kolon und Satz. München: Verlag der Bayerische Akademie der Wissenschaften.

Habineck, Thomas N. 1985. The Colometry of Latin Prose. Berkeley: The University of California Press.

Hearon, Holly E. 2004. The Implications of Orality for Studies of the Biblical Text. Oral Tradition 19(1):96-107.

Kelber, Werner H. 1983. The Oral and the Written Gospel. Philadelphia: Fortress.

Kleist, James A. 1927. Colometry and the New Testament. CB 3:18-19. 1928. Colometry and the New Testament (Concluded). $C B$ 4:26-27.

Lausberg, Heinrich. 1973. Elocutio. \$453-1082 in Handbuch der literarischen Rhetorik: eine Grundlegung der Literaturwissenschaft. Edited by Heinrich Lausberg. München: M. Hueber.

Lee, Margaret E. 1996. The Grammar of Sound in Greek Texts: Toward a Method of Mapping the Echoes of Speech in Writing. ABR 44:53-70. . 2005. A Method for Sound Analysis in Hellenistic Greek: The Sermon on the Mount as a Test Case. PhD diss., Melbourne College of Divinity. . 2018a. Sound Mapping Reassessed. Pages 8-26 in Lee, ed., 2018b. , ed. 2018b. Sound Matters: New Testament Studies in Sound Mapping. Eugene: Cascade.

Lee, Margaret E., and Bernard B. Scott. 1996. A Sound Map of the Sermon on the Mount. Pages 311367 in Treasures New and Old: Contributions to Matthean Studies. Edited by David R. Bauer and Mark A. Powell. Atlanta: Scholars Press. . 2009. Sound Mapping the New Testament. Salem: Polebridge.

Livesey, Nina E. 2012. Sounding out the Heirs of Abraham (Rom 4:9-12). Oral Tradition 27(1):273290.

Markovic, Daniel. 2006. Hyperbaton in the Greek Literary Sentence. GRBS 46:127-146.

Marschall, Priscille. 2020. Punctuating Paul's Letters in Light of the Ancient Theory of Côla and Periods: The Example of 2 Cor. 10:8-11. BibInt. 28(1):100-125.

Mathisen, Ralph W. 2008. Palaeography and Codicology. Pages 140-168 in The Oxford Handbook of Early Christian Studies. Edited by Susan A. Harvey and David G. Hunter. Oxford: Oxford University Press. 
Metzger, Bruce M. 1981. Manuscripts of the Greek Bible: An Introduction to Palaeography. Oxford: Oxford University Press.

Nässelqvist, Dan. 2015. Public Reading in Early Christianity: Lectors, Manuscripts, and Sound in the Oral Delivery of John 1-4. Leiden: Brill.

. 2018a. The Question of Punctuation in John 1:3-4: Arguments from Ancient Colometry. JBL 137(1):175-191.

. 2018b. A Sound Map of Revelation 8,7-12 and the Implications for Ancient Hearers. Pages 179-192 in Lee, ed., 2018 b.

Noël, Marie-Pierre. 1999. Gorgias et l'“invention" des ГОРГІЕІА $\Sigma$ ХНМАТА. REG 112:193-211.

Oestreich, Bernhard. 2018. Investigations into the Sound's Message of Philippians 1:27-2:18. Pages 84-119 in Lee, ed., 2018b.

Rhoads, David. 2006a. Performance Criticism: An Emerging Discipline in Second Testament Studies Part One. BTB 36:118-133. . 2006b. Performance Criticism: An Emerging Discipline in Second Testament Studies - Part Two. BTB 36:164-184. 2016. The New Testament as Oral Performance. Online: https://vimeo.com/160142546.

Scheppers, Franck. 2011. The Colon Hypothesis: Word Order, Discourse Segmentation and Discourse Coherence in Ancient Greek. Brussels: VUB Press.

. Discourse Segmentation, Discourse Structure, and Sound Mapping. Pages 133-178 in Lee, ed., $2018 b$.

Schütz, Roland. 1922a. Die Bedeutung der Kolometrie für das Neuen Testament. ZNW 21:161-184. . 1922b. Der Jakobusbrief nach Sinnzeilen ins Deutsche übertragen. Leipzig: Hinrichs. . 1928. Das Neue Testament für die deutsche Jugend nach Sinnzeiler aus dem griechischen übertragen. Leipzig: Hinrichs.

Thompson, Edward M. 1912. An Introduction to Greek and Latin Palaeography. Oxford: Clarendon. Wire, Antoinette Clark. 2011. The Case for Mark Composed in Performance. Eugene: Cascade.

Woerner, Roman. 1922. Die Frohe Botschaft nach Markus, nach Matthäus, nach Lukas, nach Johannes. München: C.H. Beck'she. . 1924. АПОКААYЧIL: das ist Offenbarung des Johannes. München: C.H. Beck’she.

\section{Ancient sources}

Alexander. De Figuris. Pages 9-40 in Rhetores Graeci, vol. 3. Edited by Leonhard von Spengel. Leipzig: Teubner, 1856.

Aquila Romanus. De Figuris. Edited and translated by Martina Elice. Hildesheim: George Olms Verlag, 2007.

Aristotle. On Rhetoric: A Theory of Civic Discourse. Translated by George A. Kennedy. Oxford: Oxford University Press, 2006.

Augustine. De Doctrina Christiana. Edited and translated by Roger P. Green. Oxford: Clarendon Press, 1995.

Cicero. Brutus. Orator. Translated by G. L. Hendrickson and H. M. Hubbell. LCL. Cambridge, MA: Harvard University Press, 1939.

. On the Orator. Translated by H. Rackham and E. W. Sutton. 2 vols. LCL. Cambridge, MA: Harvard University Press, 1942.

Dionysius of Halicarnassus. On Literary Composition. Pages 3-243 in Dionysius of Halicarnassus: Critical Essays I: On Literary Composition. Dinarchus. Letters to Ammaeus and Pompeius. Translated by Stephen Usher. LCL. Cambridge, MA: Harvard University Press, 1985. 
Hermogenes. De Ideis. Pages 20-234 in Corpus Rhetoricum IV: Prolégomènes au De Ideis. Hermogène: Les categories stylistiques du discours (De Ideis). Synopses des exposés sur les Ideai. Edited and translated by Michel Patillon. Paris: Les Belles Lettres, 2012.

Longinus. Fragments. Pages 1-234 in Longin: Fragments. Art rhétorique. Rufus: Art rhétorique. Edited and translated by Michel Patillon and Luc Brisson. Paris: Les Belles Lettres, 2001.

Pseudo-Aelius Aristides. Arts rhétoriques. Edited and translated by Michel Patillon. 2 vols. Paris: Les Belles Lettres, 2002.

Pseudo-Demetrius. On Style. Pages 307-530 in Aristotle: Poetics. Longinus: On the Sublime. Demetrius: On Style. Translated by Doreen C. Innes. LCL. Cambridge, MA: Harvard University Press, 1995.

Pseudo-Herodian. De Figuris. Edited by Kerstin Hajdú. Berlin: W. de Gruyter, 1998.

Quintilian. The Orator's Education. Translated by Donald A. Russell. 5 vols. LCL. Cambridge, MA: Harvard University Press, 2002.

Rhetorica ad Herennium. Translated by Harry Caplan. LCL. Cambridge, MA: Harvard University Press, 1954. 